\title{
Assessment of Urban Forestry in Hetauda City, Makwanpur, Nepal
}

\author{
Samana Sapkota ${ }^{1}$, Garima Sharma ${ }^{1}$, Jharna Sharma ${ }^{1,2}$, Catherine Mhae B. Jandug ${ }^{2,3}$, Deepak \\ Gautam $^{1,2^{*}}$
}

${ }^{1}$ Institute of Forestry, Tribhuvan University, Nepal

${ }^{2}$ School of Forestry, Beijing Forestry University, Beijing 100083, China

${ }^{3}$ College of Forestry and Environmental Science, Caraga State University, Philippines

\section{*Corresponding Author}

Deepak Gautam

\section{Article History}

Received: 05.01.2020

Accepted: 12.01 .2020

Published: 20.01.2020

\begin{abstract}
Trees have been an important part of human settlements throughout history. In the Nepalese context, the development of urban forestry is seen only in some cities to some extent. Questionnaire survey, key informant survey, and direct field observation techniques were used to access the information on urban forestry in Hetauda submetropolitan city which is in the phase of rapid urbanization with demanding the development of urban green infrastructure. The research aims to identify the present status of urban forestry by people's views regarding urban forestry. It also explores the list out of the preferred tree species, peoples' perception about urban forestry and new plantation site referred by people in Hetauda city. The perception of the local people towards UF was measured by the Likert scale scoring the statements on different issues. Documentation of present status and practices of urban forestry, list out of the most preferred species by the local people was recorded. Saraca indica and Azadirachta indica are the most liked species by local people for urban plantation and most of the people want greenery along the roadside.
\end{abstract}

Keywords: Hetauda Sub-Metropolitan, Development, New Plantation Site, Referred Trees, Roadside

\section{INTRODUCTION}

An urban forest is defined broadly as the natural and planted trees that are found in urban areas [1] including the associated vegetation and resources in and around dense human settlements, ranging from small communities in rural settings to metropolitan regions [2]. Urban forests are the backbone of the green infrastructure, bridging rural and urban areas and ameliorating a city's environmental footprint [3]. The $20^{\text {th }}$ century has been characterized as the century of urbanization for Europe and North America, and the $21^{\text {st }}$ century will be century of urbanization in Asia [4]. Cities reshape and alter natural landscapes as they expand, creating microclimates in which temperatures, rainfall and winds differ from those of the surrounding countryside [3].

If we talk about development of urban forestry in Nepal context, UF is seen only in some cities to some extent. There has been a practice of UF in the form of Park development and plantation [5]. Some popular parks in the urban areas of the country are- Tribhuvan Park, Godavari Park, UN Park in Kathmandu; Sahid Smarak Park in Hetauda; Basundhara Park in Pokhara; Fulbari Park in Butwal etc. The need of urban forestry has been increased when people become more aware on the importance of trees in city areas. Urban forestry development is required along the many political boundaries, property lines, road sides and different land uses throughout the city.

Hetauda is considered one of the cleanest and greenest cities in Nepal. It is also initial roadside plantation area in Nepal. But it is also being one of the victim of urbanization due to commercial, industrial, population pressure so the overall city environment is being worsened day by day alarming urban dwellers. Plantations are established, managed and maintained in Hetauda Sub Metropolitan City. As urban forestry has not been much flourished as it has to be in this area. This study will help to gain the information about peoples understanding on urban forestry and change the attitude

Copyright @ 2020: This is an open-access article distributed under the terms of the Creative Commons Attribution license which permits unrestricted use, distribution, and reproduction in any medium for non commercial use (NonCommercial, or CC-BY-NC) provided the original author and source are credited. 
of people towards urban forestry. Furthermore, it will help the management committee about the plantation site people prefer the most because of which there will be less chance of conflict between sub metropolitan and people.

\section{Materials ANd Methods Study Area}

The study was carried out in Hetauda Sub-metropolitan city which is located at a distance of $76 \mathrm{~km}$ from the capital city via the fast track, at a distance of $132 \mathrm{~km}$ via Daman and $224 \mathrm{~km}$ via Narayanghat. Lying in the central development region of the nation, it is properly situated at the central of the Makwanpur district. It lies in the $27^{\circ} 25^{\prime} \mathrm{N}$ latitude and $85^{\circ} 02^{\prime} \mathrm{E}$ longitude and is situated at a level of $300-390 \mathrm{~m}$ above the sea level Hetauda Sub-metropolitan city, 2017. It covers an area of $261 \mathrm{sq}$. km where around 254 sq.km. (97\%) is land and the remaining 7 sq.km (3\%) consists of water. It has 19 wards and is surrounded by Bakaiya Goupalika in the east, Manahari and Rakshirang Goupalika in the west, Bhimphedi, Makawanpurgadhi and Kailash Goupalika in the north and Bara district in the south. According to census 2011, Hetauda Sub metropolitan consists of 152,875 total populations. The total population of female is 77,911 and that of male is 74,964. Hetauda is one of the most diversified city in the country according to the ethnicity. The ethnic makeup of the city consists of Tamang (31.07\%), Brahmins (26.55\%), Chhetri (13.79\%), Newars $(8.80 \%)$ and others [6]

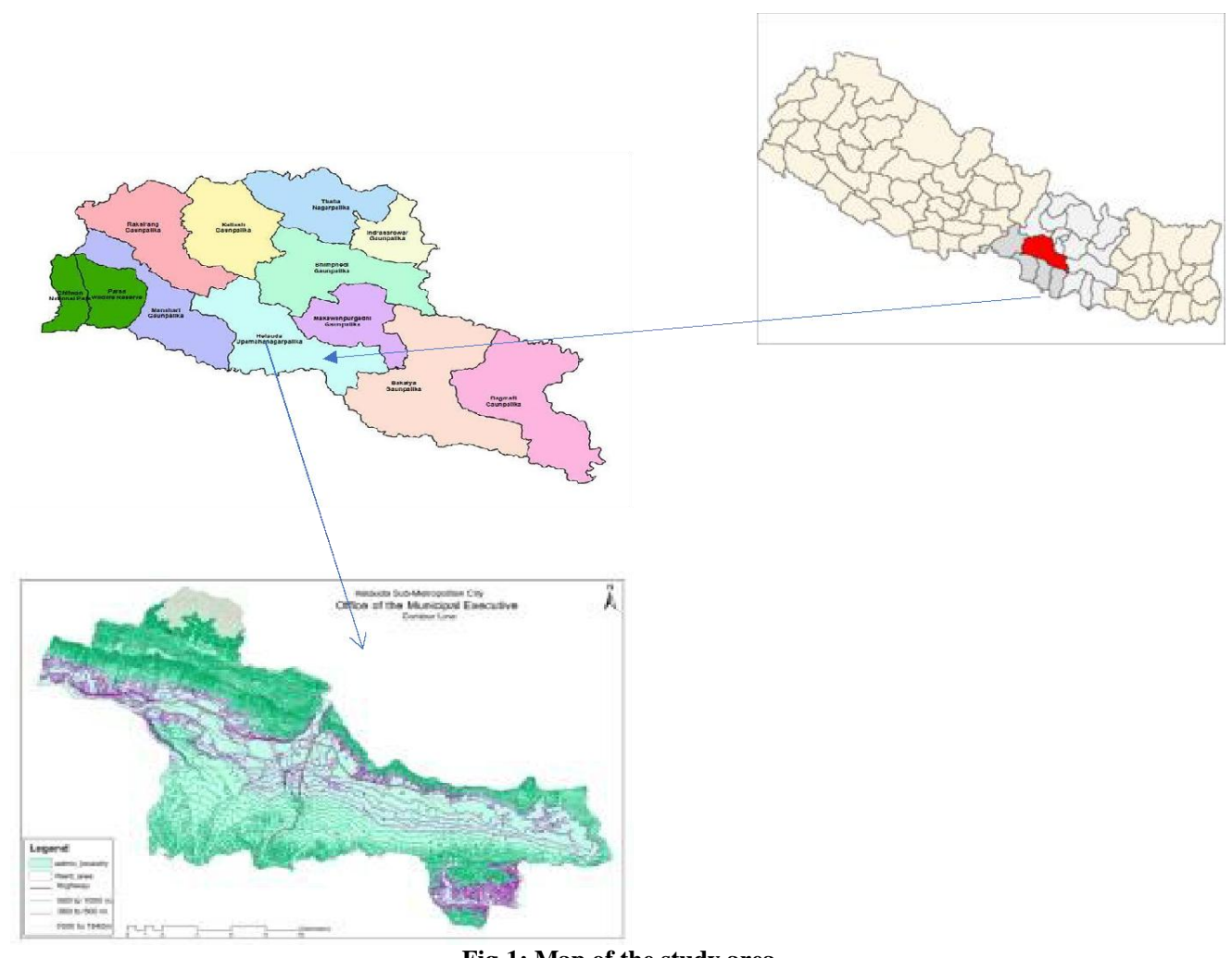

\section{Data Collection}

Direct field observation and Transect walk was carried out [7] along the city to gather information regarding present status, opportunities and problem regarding urban forestry in city also crosscheck the information we got from key informant interview and household survey. By purposive sampling, 100 household were chosen among 34,270 household in study area. Semi-structured questionnaire was prepared to collect data about people's perception regarding existing urban forestry activities. Key informant interview $(n=5)$ was conducted among members of Sub Metropolitan officers, private nurseries and also from NGOs. They were interviewed about existing situation, problem, and opportunities regarding urban forestry.

\section{Data Analysis}

The data collected from different sources has been processed, tabulated and analyzed qualitatively as well as quantitatively by using simple statistical tools like percentage, weighted mean, mean and appropriate statistical computer software like MS Excel was used in this regard. Similarly, the data obtained from the questionnaire survey was analyzed by preference ranking. 


$$
\bar{x}=\frac{w_{1} x_{1}+w_{2} x_{2}+\ldots+w_{n} x_{n}}{w_{1}+w_{2}+\ldots+w_{n}}
$$

Where

$\mathrm{x}$ is the repeating value

$\mathrm{w}$ is the number of occurrences of $\mathrm{x}$ (weight)

$\overline{\mathrm{x}}$ is the weighted mean

\section{RESULTS AND DISCUSSION}

List of Urban Tree Species Preferred by People

A total of 62 species of trees belonging to 51 genera was recorded in Makwanpur district. Shorea forest was dominant in lower elevation while Quercus forest, Alnus-Rhododendron, Quercus-Lyonia and Quercus-Symplocos forests at higher elevation. Similarly, Castanopsis tribuloides has the widest distribution range (570 $\mathrm{m}$ to $2240 \mathrm{~m}$ asl) followed by Shorea robusta, Lagerstroemia parviflora, Trichilia connaroides, Syzigium jambos, Castanopsis indica, Schima wallichii etc [8]. Most of the people prefer the trees which are beneficial for health and which are fruit bearing. Similarly, people choose species which are flowering, and which increases the aesthetic beauty of the area. People even suggested for the medicinal plants that would be beneficial for them as well as can be of multiple.

Table-1: List of preferred tree species

\begin{tabular}{|l|l|l|}
\hline Botanical Name & Family & Local Name \\
\hline Saraca indica & Legumes & Ashok \\
\hline Pterocarpus santalinus & Legumes & Raktachandan \\
\hline Cinamomum tamala & Lauraceae & Tejpatta \\
\hline Litchi chinensis & Sapindaceae & Lichi \\
\hline Santalum album & Santalaceae & Shrikhanda \\
\hline Ficus religiosa & Moraceae & Pipal \\
\hline Cinamomum camphora & Lauraceae & Kapoor \\
\hline Juniperus Indica & Cypress & Dhupi \\
\hline Rauvolfia serpentine & Apocynaceae & Sarpaganda \\
\hline Mangifera indica & Anacardiaceae & Aanp \\
\hline Azadirachta indica & Meliaceae & Neem \\
\hline Nyctanthes arbor-tristis & Oleaceae & Parijaat \\
\hline Pinus roxburghii & Coniferae & Salla \\
\hline Bombax ceiba & Malvaceae & Simal \\
\hline
\end{tabular}

Peoples' Perception towards urban trees

Table-2: People's perception towards urban forestry

\begin{tabular}{|l|l|l|l|l|l|l|l|}
\hline \multicolumn{1}{|c|}{ Considered Statements } & \multicolumn{3}{|c|}{$\begin{array}{c}\text { Percentage of } \\
\text { responses }\end{array}$} & \multicolumn{2}{|c|}{ wt. } \\
mean & Perception \\
\cline { 2 - 6 } & $\mathbf{1}$ & $\mathbf{2}$ & $\mathbf{3}$ & $\mathbf{4}$ & $\mathbf{5}$ & & \\
\hline 1. Do you think urban forestry program will expand? & 3 & 2 & 6 & 17 & 72 & 4.55 & SA \\
\hline 2. Do you expect any benefits from urban forest? & 2 & 6 & 9 & 23 & 60 & 4.33 & A \\
\hline 3. Do you think trees in the urban areas increases its beauty? & 0 & 5 & 13 & 58 & 24 & 4.01 & A \\
\hline 4. Do you think trees in the urban areas reduce its air pollution? & 0 & 0 & 2 & 10 & 88 & 4.86 & SA \\
\hline $\begin{array}{l}\text { 5. Do you think urban forest maintenance and management is done } \\
\text { by government and local people participation? }\end{array}$ & 4 & 12 & 36 & 33 & 15 & 3.43 & UD \\
\hline $\begin{array}{l}\text { 6. Is there urgent necessary to launch efficient urban forestry } \\
\text { program? }\end{array}$ & 0 & 7 & 24 & 58 & 11 & 3.73 & A \\
\hline 7. Do you want to participate in any urban tree activities? & 0 & 5 & 0 & 37 & 58 & 4.48 & A \\
\hline 8. Has the tree along roadside been planted according to your desire? & 30 & 15 & 12 & 15 & 28 & 2.96 & UD \\
\hline $\begin{array}{l}\text { 9. Are you satisfied with availability current trees species along } \\
\text { roadside? }\end{array}$ & 12 & 8 & 5 & 24 & 51 & 3.94 & SA \\
\hline 10. Are you satisfied with the current tree species? & 7 & 11 & 43 & 25 & 14 & 3.28 & A \\
\hline 11. Trees along roadside are hazardous to your home and life? & 32 & 34 & 15 & 12 & 7 & 2.28 & UD \\
\hline 12. Do you feel that trees along roadside are yours? & 1 & 4 & 23 & 44 & 28 & 3.94 & A \\
\hline
\end{tabular}


Samana Sapkota et al., South Asian Res J Human Soc Sci; Vol-2, Iss- 1 (Jan-Feb, 2020): 4-9

\begin{tabular}{|l|l|l|l|l|l|l|l|}
\hline 13. Do you want more trees (without any hazards) along roadside? & 0 & 1 & 2 & 58 & 39 & 4.35 & SA \\
\hline $\begin{array}{l}\text { 14. The poor management of roadside trees is due to lack of your } \\
\text { participation }\end{array}$ & 3 & 6 & 28 & 49 & 14 & 3.65 & $\mathrm{~A}$ \\
\hline $\begin{array}{l}\text { 15. Do you think peoples' participation is essential for urban tree } \\
\text { management? }\end{array}$ & 2 & 3 & 16 & 56 & 23 & 3.95 & $\mathrm{~A}$ \\
\hline
\end{tabular}

Note: 1 - Strongly disagree (SD); 2 -Disagree (D); 3 -Undecided (UD); 4 -Agree (A); 5 - Strongly Agree (SA).

Level of participation

\begin{tabular}{|c|c|c|c|c|c|}
\hline \multirow{2}{*}{ Considered Statements } & \multicolumn{5}{|c|}{ Percentage of responses } \\
\hline & 1 & 2 & 3 & 4 & 5 \\
\hline $\begin{array}{l}\text { 1. Do you think urban forest maintenance and management is done by } \\
\text { government and local people participation? }\end{array}$ & 4 & 12 & 36 & 33 & 15 \\
\hline 2. Do you want to participate in any urban tree activities? & 0 & 5 & 0 & 37 & 58 \\
\hline 3. Do you feel that trees along roadside are yours? & 1 & 4 & 23 & 44 & 28 \\
\hline 4. The poor management of roadside trees is due to lack of your participation & 3 & 6 & 28 & 49 & 14 \\
\hline 5. Do you think peoples' participation is essential for urban tree management? & 2 & 3 & 16 & 56 & 23 \\
\hline Mean & 2 & 6 & 20.6 & 43.8 & 27.6 \\
\hline
\end{tabular}

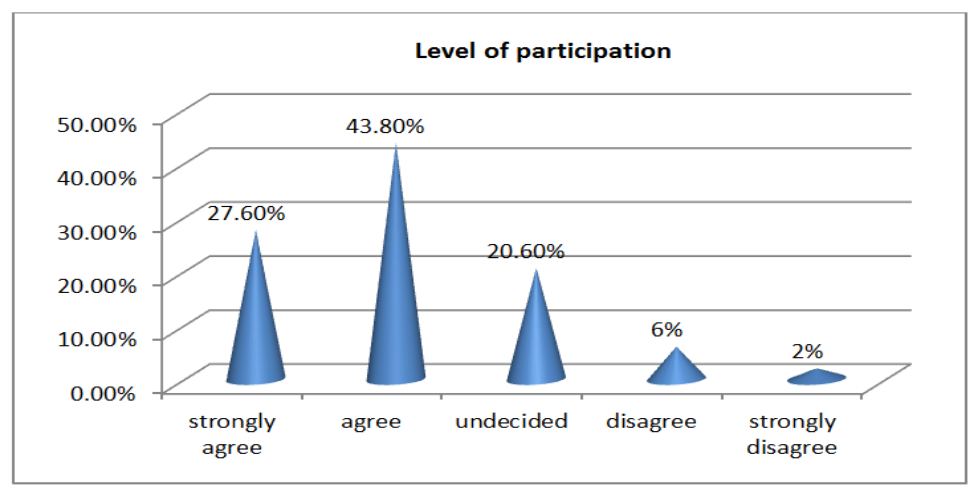

Fig-2: Level of participation

From the figure above it is found that $27.60 \%$ of the respondents strongly agree with the activities regarding urban forestry. Similarly, $43.80 \%$ agree with this phenomenon. Like wisely $20.60 \%$ of respondents are found to be undecided. In the same way $6 \%$ respondents disagreed with urban forestry activities. Around $2 \%$ respondents are found to be strongly disagreed.

\section{Level of benefits}

Table-4: Level of benefits

\begin{tabular}{|l|l|l|l|l|l|}
\hline Considered Statements & \multicolumn{5}{l|}{ Percentage of responses } \\
\cline { 2 - 6 } & $\mathbf{1}$ & $\mathbf{2}$ & $\mathbf{3}$ & $\mathbf{4}$ & $\mathbf{5}$ \\
\hline 1. Do you think urban forestry program will expand? & 3 & 2 & 6 & 17 & 72 \\
\hline 2. Do you expect any benefits from urban forest? & 2 & 6 & 9 & 23 & 60 \\
\hline 3. Do you think trees in the urban areas increases its beauty? & 0 & 5 & 13 & 58 & 24 \\
\hline 4. Do you think trees in the urban areas reduce its air pollution? & 0 & 0 & 2 & 10 & 88 \\
\hline Mean & $\mathbf{1 . 2 5}$ & $\mathbf{3 . 2 5}$ & $\mathbf{7 . 5}$ & $\mathbf{2 7 . 4}$ & $\mathbf{6 1}$ \\
\hline
\end{tabular}

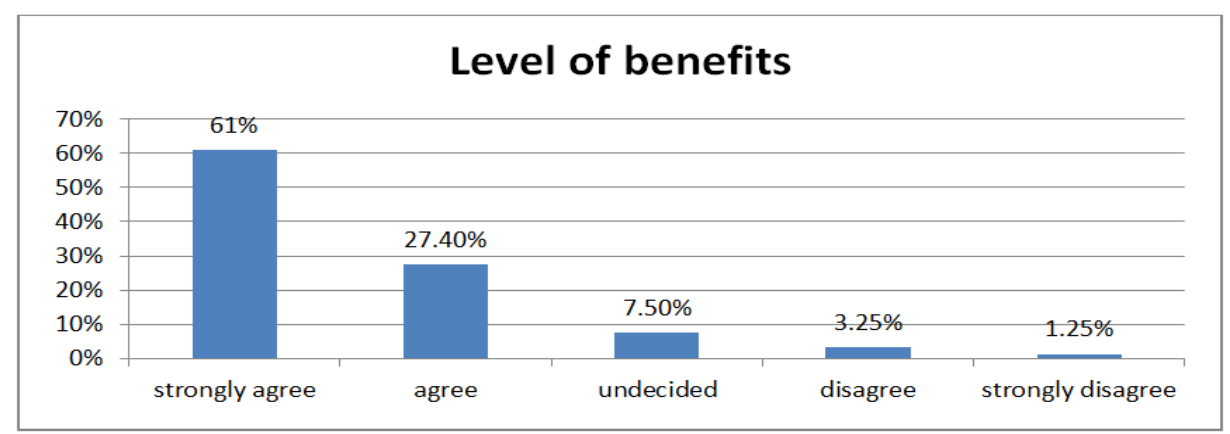

Fig-3: Level of benefits 
In accordance with above graphical representation, it is stated that $61 \%$ respondents are found to be strongly agreed with the overall benefits of urban forestry where pollution control, aesthetic beauty, fresh air(oxygen) were noted more. In the same pattern $27.4 \%$ are found to be agreed on beneficial aspect of urban forestry; however, $7.5 \%$ are found to be undecided. Ultimately $3.25 \%$ respondents disagree on the aspect regarding urban forestry awareness activities and $1.25 \%$ is found to be strongly disagreed.

\section{Level of Satisfaction}

Table-5: Level of satisfaction

\begin{tabular}{|l|l|l|l|l|l|}
\hline Considered Statements & \multicolumn{3}{l|}{ Percentage of responses } \\
\cline { 2 - 6 } & $\mathbf{1}$ & $\mathbf{2}$ & $\mathbf{3}$ & $\mathbf{4}$ & $\mathbf{5}$ \\
\hline 1. Is there urgent necessary to launch efficient urban forestry program? & 0 & 7 & 24 & 58 & 11 \\
\hline 2. Are you satisfied with availability current trees species along roadside? & 12 & 8 & 5 & 24 & 51 \\
\hline 3. Are you satisfied with the current tree species? & 7 & 11 & 43 & 25 & 14 \\
\hline 4. Do you want more trees (without any hazards) along roadside? & 0 & 1 & 2 & 58 & 39 \\
\hline Mean & $\mathbf{4 . 7 5}$ & $\mathbf{6 . 7 5}$ & $\mathbf{1 8 . 5}$ & $\mathbf{4 1 . 2 5}$ & $\mathbf{2 8 . 7 5}$ \\
\hline
\end{tabular}

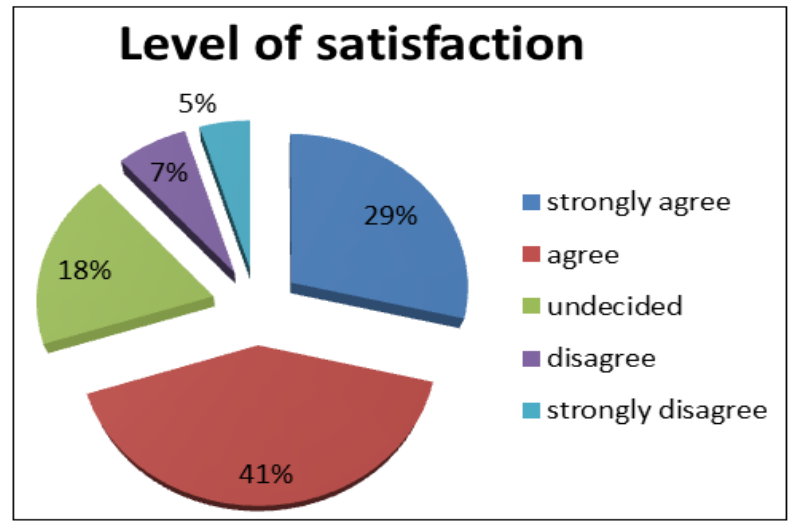

Fig-4: Level of satisfaction

From the above pie-chart it is found that $28.75 \%$ of the respondents strongly satisfied with the activities regarding urban forestry. Similarly, $41.25 \%$ agree with this phenomenon. Like wisely $18.50 \%$ of respondents are found to be undecided. In the same way $6.75 \%$ respondents disagree with urban forestry activities. Around $4.75 \%$ respondents are found to be strongly disagreed.

\section{New plantation site preferred by people}

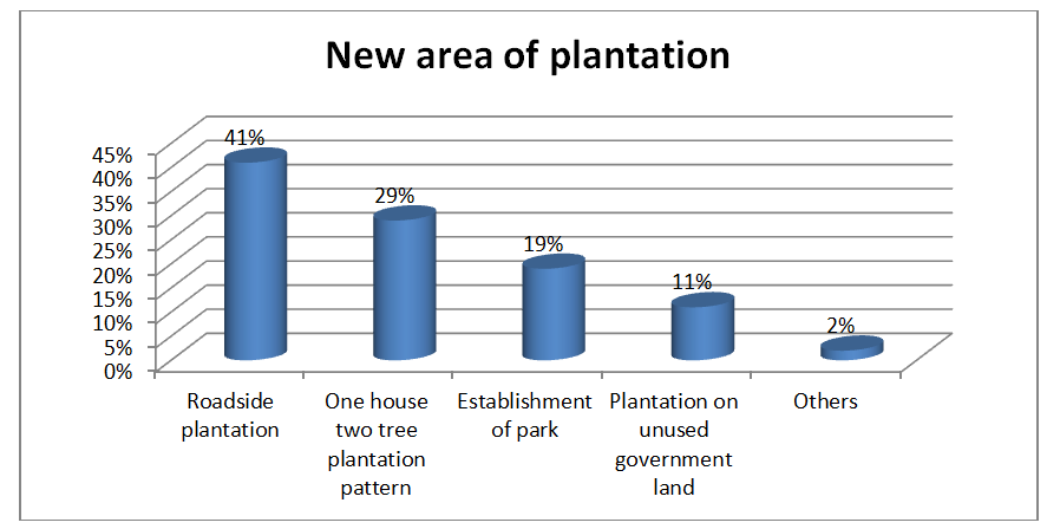

Fig-5: New plantation site preferred by people

From the above data we can say that, people preferred first plantation site is roadside plantation where $41 \%$ agree for it. Similarly, 29\% people prefer one house two tree plantation pattern which can be useful for the management committee to develop next project for the development of the urban forestry in study area. Accordingly, people third choice is establishment of park (19\%) and plantation on unused government land (11\%) is fourth. Some of the people are even found that they do not prefer any of the option above and choose others if there is any other better option than these 
four. Some people prefere easy availability of fodder for their cattles as like people of Gorkha [9]. Few people who live near by forestry campus want urban forestry as like corridor of habitat, like biological corridors.

\section{CONCLUSION}

Based on our study we can conclude that urban forestry practices existing in the study area are urban park, roadside plantation, and urban forest. People preferred tree species like Saraca indica (Ashok), Azadirachta indica (Neem), Nyctanthes arbor-tristis (Parijat), Juniperus Indica (Dhupi). One of the major challenges for urban forestry development in the study area was the lack of proper policy and legal framework. Other challenges are finance, proper caring, and timely management of the urban trees. Most people are aware of the benefits of urban forestry so they want proper management of urban forestry especially roadside plants. They want to identify the most preferred site for the new plantation which can reduce the conflicts between the government and the public. People want fast-growing and easily surviving evergreen species for the roadside plantation. Most of them are satisfied with the roadside plantation of Saraca indica in Hetauda city.

\section{ACKNOWLEDGMENTS}

We would like to express my gratitude to the residents of Hetauda sub-metropolitan city for their support and Mr. Rohit Khatiwada and Ms. Poonam Ghimire for the guidance before and during my research work.

Conflict of interest: The author declares no conflict of interest.

\section{REFERENCES}

1. Ordonez and Duinker. (2010). Climate change mitigation and adaptation in urban forest: a framework for sustainable urban forest management.

2. Nowak, D., Noble, M., Sisinni, S., \& Dwyer, J. (2001). People and Trees: Assessing the US Urban Forest Resource. Journal of Forestry. 99:37-42.

3. Catapano, A. L., Graham, I., De Backer, G., Wiklund, O., Chapman, M. J., Drexel, H., ... \& Reiner, Ž. (2016). 2016 ESC/EAS guidelines for the management of dyslipidaemias. European heart journal, 37(39), 2999-3058.

4. Nilsson, K., Randrup, T. B., \& Schipperijn, J. (2005). Urban forests and trees.

5. Bista, R. (2009). Institutional involvement and peoples' perception towards urban Forestry, a case Study of Lalitpur Sub-Metropolitan City, Nepal. A. B.Sc. Forestry Research Thesis Submitted to Tribhuwan University, Institute of Forestry, Pokhara, Nepal.

6. Hetauda Sub Metropolitan Office, 2016/17 Hetauda city profile 2016/17

7. Gautam, D., Bhattarai, S., Sigdel, R., Jandng, C. M. B., \& Mujahid, A. (2019). Climate variability and wetland Resource in Rupa Lake Catchment, Nepal. http://twasp.info/journal/home. https://doi.org/10.5281/zenodo.3568477

8. Bhattarai, S., Bhatta, B., Tamang, R. (2018). Distribution pattern of tree species from tropical to temperate regions in Makawanpur district, central Nepal. Banko Jankari, Vol. 28. 2018.

9. Khanal, D., Gautam, D., Bhandari, J., Bhattarai, S., Gahatraj, G., Jandug, CM.B.,Baral,K. (2020). Contribution of Leasehold Forestry to Users Household Income in Sahidlakkhan Rural Municipality, Gorkha, Nepal. http://twasp.info/journal/home. DOI: https://doi.org/10.5281/zenodo.3598134 